\title{
KÖNYVJELZÖ
}

\section{JAMES WESLEY SCOTT (ED.): EU ENLARGEMENT, REGION BUILDING AND SHIFTING BORDERS OF INCLUSION AND EXCLUSION}

\author{
(Ashgate, London, 2006, 245 o.)
}

\section{IMRE GABRIELLA}

James Wesley Scott Európai bővités, regionális fejlödés, a befogadás és a kizárás változó határai címet viseló könyve 2006-ban jelent meg a londoni Ashgate Kiadó Border Regions sorozatában, amelynek egyes kötetei a határrégiókkal kapcsolatos legfrissebb empirikus és elméleti kutatások eredményeit mutatják be.

A 2004-es év történelmi jelentőségű esztendő volt az európai bỏvítési folyamatban: nyolc közép-kelet-európai állam, valamint Málta és Ciprus csatlakozott az Európai Unióhoz. A Közösség 2007-ben Románia és Bulgária csatlakozása révén további két taggal bóvült. Az új tagok felvétele az EU külsö határainak fokozatos megváltozásán túl a határrégiókban társadalmi-gazdasági és politikai átalakulási folyamatokat eredményezett, amelyek egyrészt új területfejlesztési lehetöségeket hordoznak magukban, másrészt azonban problémák és feszültségek forrásai is lehetnek. Az Európai Unió a Tágabb Európa címú stratégiai dokumentum és a határ menti együttmüködések támogatása iránti hosszú távú elkötelezettsége által kifejezte, hogy el szeretné kerülni a „Kelet” és „Nyugat” közötti új törésvonal kialakulását, és az új szomszédsági eszköz létrehozása által javítani szeretné a nem uniós európai országokkal fenntartott kapcsolatok anyagi és intézményi hátterét. Miközben azonban az uniós politikák számos alkotóeleme segíti a külső határon átnyúló együttmüködések kialakítását, más összetevők a kapcsolatok megerỏsödése ellen dolgoznak. Az elválasztó szerepet hangsúlyozó határrendszer kiépítését célzó tervek és a gazdasági protekcionizmus az egyưttmúködés ösztönzői és a „befogadás” diplomáciai erőfeszítései ellen hatnak. Ma még nem látható világosan, hogy az uniós és nem uniós tagállamok közötti regionális partnerségi kapcsolatok a piaci logikán túl is összekapcsolják-e majd az eltérő gazdasági, társadalmi és politikai entitásokat, és a kizáró eljárások (pl. a nem uniós állampolgárok számára előírt vízumkötelezettség) nem teszik-e lehetetlenné az együttmüködést. Mindenesetre az EU átalakuló határai mentén ki kell alakítani azokat a mechanizmusokat, amelyek képesek közvetíteni a 
külső kényszerek és az „Európa Eröddel” kapcsolatos helyi félelmek között, és túlmutatnak a gazdasági, társadalmi és politikai aszimmetriákon.

Az Európai bövités, regionális fejlödés, a befogadás és a kizárás változó határai címủ könyv a kelet-közép-európai határterületekröl készült esettanulmányokat tartalmaz, amelyek az uniós bővítés fényében értelmezik a határok átstrukturálódási folyamatát, bemutatják az egyes határrégiók fejlesztési kapacitásait, és lehetséges továbbfejlesztési irányokat fogalmaznak meg az EU Tágabb Európa koncepciója számára.

A könyv négy nagyobb fejezetre osztható. Az elsö két fejezet az uniós bővítés geopolitikai következményeit, illetve az új külső határokra gyakorolt hatásait vizsgálja. A harmadik rész az új határokon megvalósuló együttmüködések hétköznapi gyakorlatára és regionális beágyazottságára összpontosít, míg a negyedik az egykori uniós külső határokon zajló regionális fejlesztési együttmüködések eredményeit értékeli.

\section{I) Az EU-bövités határai és geopolitikája}

Az EU-bövítés geopolitikai következményeivel foglalkozó elsö fejezet három tanulmányt tartalmaz. James Wesley Scott az EU Tágabb Európa koncepcióját elemzi. Bemutatja a kezdeményezés ủj külső határokon kialakult együttmüködésekre gyakorolt hatásait és az uniós szomszédságpolitika elött álló kihívásokat. Különös figyelmet szentel azoknak a térségeknek, ahol az együttmüködésnek a területi tervezés egymásnak ellentmondó logikája és a kulturális különbségek miatt számos akadálya van: részletesen elemzi az északi szomszédokkal (elsősorban Oroszországgal) és a volt gyarmatokkal (Maghreb-országok, Közel-Kelet és a mediterrán térség) fenntartott kapcsolatokat. A szerző véleménye szerint ezekben a régiókban a partnerség és a szabadkereskedelem lehetnek azok az integratív mechanizmusok, amelyek a jövőben helyettesíthetik az uniós tagság ígéretét.

A Bizottság Tágabb Európa koncepciója az EU új geopolitikai célkitüzéséről tanúskodik, amelynek értelmében a Közösség igyekszik szorosabbra füzni kapcsolatait a szomszédos államokkal és elkerülni az ủj törésvonalak kialakulását Európában. A regionális partnerségi kapcsolatok alapját a kölcsönös és pozitív értelemben vett politikai és gazdasági egymásrautaltság képezi, amely a biztonság, a stabilitás és a fenntartható fejlődés elömozdításának legföbb eszköze a térségben. Scott bemutatja az EU geopolitikai törekvéseire jellemző ellentmondásokat is. Véleménye szerint a Tágabb Európa koncepció nem fektet kellỏ hangsúlyt az együttmüködő felek közti gazdasági-politikai aszimmetriákra és hatalmi aránytalanságra, de nem foglalkozik eléggé a külső határok mentén életbe léptetett szigorúbb ellenörzési rendszer határokon átívelö kapcsolatok kiépülését korlátozó hatásaival sem. A Tágabb Európa kezdeményezés elött álló legnagyobb kihívás, hogy megtalálja a befogadó és kizáró eljárások közötti egyensúlyt az EU új külső határain.

Gabriel Popescu a román-ukrán-moldáv határrégió uniós bövítés utáni perspektíváit vázolja esettanulmányában. Az elmúlt évtizedben a három ország kormányai területi vitáikat félretéve lépéseket tettek a korábban szigorú határőrizeti rendszer liberalizálására, és támogatták a térségben az eurorégiók létrehozását is. Bár a kor- 
mányok közötti nézeteltérések továbbra is beárnyékolják a kapcsolatokat, a határon átnyúló helyi együttmüködések jelentősége megnőtt, és 2002-ig négy eurorégió is megalakult a román-ukrán-moldáv határrégióban. Ezek az eurorégiók - nyugateurópai elödeikkel ellentétben — felülröl létrehozott intézmények, ahol az állam teljes ellenörzést gyakorol a döntéshozatali mechanizmus felett. A hatalom helyi önkormányzati szervekre történő átruházása valójában nem történik meg, a szervezetek gyakorlatilag a belpolitika eszközei a nemzetközi politikai színtéren. Az eurorégiók jelentősége abban rejlik, hogy keretet biztosítanak a nemzeti kormányok számára a vitatott területi kérdések kezelésére.

Románia Közösséghez való csatlakozásával e határszakaszokon ủjra szigorúbb határőrizeti rendszer lesz érvényben, ami ugyan megoldást kínálhat a térség felöl érkező biztonsági fenyegetések (illegális bevándorlás, szervezett bünözés) kiszürésére, azonban negatív következményei vannak a határon átnyúló kapcsolatok szempontjából. Ma még nem tudható, hogy az új uniós szomszédságpolitika (és különösen a határon átnyúló projektek számára igénybe vehetô pénzügyi eszköz) biztosítja-e majd az eredményes együttmüködéshez, a kölcsönös függőségi kapcsolatok kialakulásához nélkülözhetetlen kereteket.

Henk van Houtum és Roos Pijpers ,zárt közösség”-ként jellemzik az Európai Uniót. A bỏvítési folyamat felerösítette a tömeges bevándorlástól való félelmet, ami nemcsak az új tagállamok állampolgárainak szabad munkavállalását átmenetileg korlátozó intézkedésekben jelentkezik, hanem a külső határok ellenőrzésének szigorításában is testet ölt. Az EU külső határai ugyanis mind a társadalmi jóléti mutatók, mind a rendszerváltás folyamatának elörehaladottságát illetően szimbolikus határoknak tekinthetők.

A szerzők véleménye szerint az Unió bevándorlás- és határpolitikája azonban meglehetősen ellentmondásossá válik azáltal, hogy a szigorításokkal és korlátozásokkal egyidejűleg egyre több kísérlet történik az EU-n kívülről érkezö, de a Közösség szảmára „kívánatosnak” minösülő bevándorlók kiszürése érdekében, melynek a célja, hogy megszüntessék az európai gazdaság egyes területein jelentkező munkaerőhiányt. A tanulmány segít az egyidejüleg „,kizáró” és „szelektív” eljárások okainak megértésében. A szerzőpáros a jövőben elkerülhetetlennek tartja a bevándorlást és a külső határok örizetét érintő szabályozás enyhülését, és egy szolidárisabb, az uniós határokon túlról érkezőkkel törődő politika megfogalmazását.

\section{II) Az EU-bövités hatásai az új külsỏ hatórokon}

A könyv második fejezetében található négy esettanulmány áttekintést ad a bővítés utáni helyzetről az EU ủj külsö határán. Nagy Imre és Hajdú Zoltán Magyarország határainak változó jelentőségére hívják fel a figyelmet. 1989 után Magyarország geopolitikai helyzetének és lehetőségeinek megítélése radikális változáson ment keresztül. A kétpólusú világrend megszünésével az ország - a volt szocialista blokkba tartozó szomszédaihoz hasonlóan - igyekezett újradefiniálni nemzetközi kapcsolatait, és új külpolitikai célokat határozott meg a kibővülő Európai Unióban. 
Tér és Társadalom 21. évf. 2007/4. 213-234. p.

Ezzel egyidejüleg a közvetlen szomszédokkal is fejlődtek a kétoldalú kapcsolatok, ami a környezö államok határrégióiban élő nagyszámú magyar nyelvü kisebbség miatt bírt különösen nagy jelentőséggel. A hidegháború utáni években a magyar határok jelentösége a határon átnyúló kapcsolatok szempontjából nagymértékben megnövekedett. Ez érvényes a régi szomszédokra (Ausztria, Románia) és a nemrégiben függetlenné vált új szomszédokra (Szlovákia, Ukrajna, Szerbia, Horvátország, Szlovénia) is. A tanulmány több szempont alapján jellemzi Magyarország egyes határainak megváltozott geopolitikai jelentőségét a rendszerváltás után, és bemutatja a politikai átalakulás legfontosabb állomásait.

Olga Mrinska tanulmányában a bövítésnek az EU egyik legnagyobb új szomszédjára, Ukrajnára gyakorolt hatásait vizsgálja. Azt állitja, hogy Ukrajna közvetlen uniós szomszéddá válása messzire ható következményekkel jár az ország területi fejlődése szempontjából.

Ukrajna az úgynevezett Huntington-vonal mentén egy Közép-és Nyugat-Európa felé nyitott nyugati és egy Oroszország felé orientálódó keleti részre osztható. Nyugat-Ukrajna Lengyelországgal, Szlovákiával, Magyarországgal és Romániával közös történelme és a társadalmi és kulturális hasonlóságok elösegítették az Európai Közösséghez füződő hivatalos és nem-hivatalos kapcsolatok kialakulását. KeletUkrajna történelme viszont évszázadokon keresztül Oroszországhoz kötödött, így ennek az országrésznek a fejỏdésére az orosz kultúra és az orosz nyelv gyakorolt komoly hatást.

A szerző az elmúlt évek gazdasági teljesitménye alapján vázolja a kilenc ukrán makrorégió gazdasági kilátásait. Míg a keleti területek fejlett nehézipari központjai továbbra is szerkezetátalakítási problémákkal küzdenek, a nyugatabbra fekvő, döntően elmaradott, mezőgazdasági jellegü régiók a kibövült EU közelségének köszönhetően az elmúlt években egyre több külföldi befektetőt vonzottak. Mivel az uniós bövítési folyamat hozzájárulhat a kelet és nyugat között meglévö szakadék mélyüiléséhez, a kormány regionális politikájának hozzá kell járulnia a két országrész közötti szoros partnerségi kapcsolatok kialakulásához, ami lehetővé tenné a későbbi tapasztalatcserét. Egy esetleges „zárt európai klub” kialakulása azonban, amely nem ismeri el az ukrán állam európai természetét és aspirációit, az ukrán lakosság oroszbarát érzelmeinek felerősödéséhez is vezethet.

Tatiana Zhurzhenko az uniós bővítés ukrán-orosz határra gyakorolt lehetséges hatásait és a két ország közötti határon átnyúló kapcsolatok perspektíváit vizsgálja. A kapcsolatok alakulását jelentősen befolyásolja, hogy az ukrán társadalom kettészakadni látszik a keleti és a nyugati integrációs elképzelések mentén. A szerző számára központi kérdés, hogy az EU ủj szomszédsági politikája értelmezhető-e az Oroszország által vezetett, szovjet utódállamokra kiterjedő integrációs elképzelések geopolitikai alternatívájaként, illetve, hogy ebben a helyzetben milyen változásokat hozhat Ukrajnának a „Tágabb Európa” stratégia intézményesülése és az ország új „szomszédi” státusza. Jelenleg úgy tủnik, hogy Ukrajna keleti határait illetően az uniós szándék alapvetően az illegális bevándorlás megakadályozására és a határellenörzés hatékonyságának javitására irányul. Kérdéses, hogy az uniós bővítés érdekeltté 
Tér és Társadalom 21. évf. 2007/4. 213-234. p.

teszi-e a Közösséget a biztonsági problémák megelözésén túl a határon átívelö gazdasági és humanitárius együttmüködés támogatásában is. Zhurzhenko az ukrán-orosz határon megalakult első eurorégiót mutatja be tanulmányában, amely az európai és posztszovjet integrációs tervek egymást átfedő folyamatai során jött létre.

Ilkka Liikanen és Petri Virtanen a Finnország és Oroszország közti uniós külső határszakaszon zajló folyamatokat elemzik, különös tekintettel az Euroregio Kareliára, amely mintaként szolgálhat a bővítés elötti határokon megvalósuló regionális együttműködések számára. A szerzők először az uniós irányelveket, a határ menti együttmüködés eszközeit és ezek európai határpolitikában betöltött szerepét mutatják be. Kiemelt figyelmet fordítanak a Tágabb Európa stratégiára és az új szomszédsági eszköz határ menti kapcsolatokra gyakorolt hatásaira az unió keleti határán. Vázolják a finn-orosz határrégió történelmi-politikai fejlödését is, hogy képet adjanak arról a környezetről, amelyben a határ menti együttműködés új eszközei alkalmazásra kerülnek. A tanulmány befejezö része a regionális intézményi innovációknak az új uniós szomszédsági program alkalmazásában betöltött lehetséges szerepét tekinti át.

\section{III) Az együttmüködés kereteinek kialakitása és a határon átnyúló regionális fejlödés}

A könyv harmadik fejezete a határ menti együttmüködések hétköznapi gyakorlatára és regionális beágyazottságára összpontosít. Alla Skvortova bemutatja, hogy a bövítés és az uniós politikák hogyan befolyásolták a határon átnyúló együttműködési mechanizmusok, különösen az eurorégiók fejlődését a moldáv-román határon. A szerző rövid áttekintést ad a két ország közötti kapcsolatok történetéröl, és vázolja az egyưittmúködés kereteinek fejlődését Moldova függetlenné válása óta. A két országot kulturális és nyelvi szálak, valamint a közös történelmi múlt is összeköti. Amint Skvortova kihangsúlyozza, a hasonlóságok nem segítettek mindig a politikai feszültségek leküzdésében, bár a moldván döntéshozók lassanként kezdik felismerni, hogy a román támogatást és tapasztalatokat hasznosítani tudják az EU-val folytatott saját tárgyalásaik során is. A szerző úgy véli, hogy az Európai Bizottság Tágabb Európa koncepciója nagyon pozitív hatást gyakorol a tagjelölt országok és szomszédaik együttmüködésére, és segíti a biztonság és stabilitás megteremtését a jövőbeli uniós határokon.

Baranyi Béla röviden összefoglalja a Magyarország keleti határain (a magyarukrán és a magyar-román határrégióban) folytatott komplex kutatás eredményeit. A szerző a határ menti periférikus területek jelenlegi helyzetével és fejlödési lehetöségeivel foglalkozik, és arra a kérdésre keresi a választ, hogy a határ menti egyuittmúködés különböző formái hogyan járulnak hozzá a regionális fejlódéshez. A tanulmány a magyar-román, magyar-ukrán határterületek speciális problémáinak áttekintésével indul, és bemutatja, hogy a történelmi folyamatok és a posztszocialista átalakulás során hogyan váltak ezek a területek a „periféria perifériájá"vá. Ezután a szerző áttekinti a már régebb óta létező (és meglehetősen nagy kiterjedésú), valamint az újonnan alakult kisebb eurorégiókat és a települések közötti 
együttmüködéseket. A megyei és a helyi szintủ regionális szervezetek alternatívát jelentenek a több országra kiterjedö, nehézkesen müködő együttmüködésekkel szemben, és jelentőségük egyre növekszik a határon átnyúló kapcsolatok létrehozásában. Baranyi véleménye szerint a helyi szintủ együttmüködések fokozatosan hozzájárulnak a gazdasági terek és a határok által évtizedekre elválasztott városi piacok integrációjához, bár számolni kell az új határőrizeti rendszer kiépülésének rövid- és középtávú negatív hatásaival is.

Szabó Gyula és Koncz Gábor a határon átnyúló kapcsolatok helyi szintü vonatkozásait vizsgálja a magyar-román határrégióban. A kutatás öt határ menti település lakosságára terjedt ki, és a határ emberek közötti személyes kapcsolatokra gyakorolt hatásait vizsgálta. A vizsgált települések egy része jelenleg is rendelkezik már határátkelöhellyel, más részüknél a közeljövőben tervezik annak megépítését.

A tanulmány legföbb célja, hogy az eurorégiós szerveződéseken belül felmérje a helyi szintủ együttmüködések hatékonyságát és életképességét. A szerzők röviden vázolják az egyes szerveződések és az érintett önkormányzatok között kialakult kapcsolatok típusait és megvizsgálják, hogy a jövőbeli céljaikat figyelembe véve milyen mértékben egyeznek a két szint érdekei és stratégiải. A tanulmány végén a magyar-román kezdeményezések sikereinek és kudarcainak lehetséges okai kerülnek bemutatásra.

Balcsók István és Dancs László a külföldiek legális és illegális foglalkoztatásának kérdését tárgyalja a magyar-ukrán határszakasz vonatkozásában. 1989 előtt Magyarország keleti határai mentén nem volt jelentős a határ menti munkaerő-áramlás, a gazdasági kapcsolatokat szigorúan szabályozták. A szocialista rendszer bukása után a határok megnyíltak, és a szomszédos területek megkezdték a társadalmi és a piaci kapcsolatok kiépítését, megindult a határrégiók közötti együttmüködés is.

A tanulmány a hatékony munkaerő-piaci együttmüködés lehetỏségeit vizsgálja Magyarország keleti határai mentén. A szerzők figyelembe veszik, hogy a vizsgált területek az elsô világháború elötti időszakban gazdasági és politikai szempontból összetartozó egységek voltak, amelyek a piaci vonzáskörzetek megcsonkítása és a szocialista időszak alatti elszigeteltség miatt ma periférikus területeknek számítanak, ráadásul a piacgazdaság új szabályaihoz történő alkalmazkodás is kihívást jelent. A munkaerő-piaci kapcsolatok vizsgálatát a szerzők azért tartják fontosnak, mert a magyar munkaerőpiac az EU-tagságnak köszönhetően vonzóbbá vált a külföldiek számára és az ország a kelet-nyugati irányú munkaerö-áramlásban központi szerepet tölthet be. A határ menti foglalkoztatás (legális és illegális egyaránt) már ma is számos kárpátaljai család megélhetésének legföbb forrását jelenti. A munkaerő-piaci kapcsolatok helyi jelentőségének ellenére Balcsók és Dancs szerint valószínütlen, hogy nagyszámú külföldi munkavállaló érkezzen a régióba, mivel az túl periférikus helyzetü és a foglalkoztatási központok elég messze vannak egymástól. Ráadásul az EU külső határának számító ukrán-magyar határszakaszon az elkövetkező években a szigorú schengeni szabályok maradnak érvényben. 
Tér és Társadalom 21. évf. 2007/4. 213-234. p.

A fejezet utolsó tanulmányában Katarzyna Krok és Maciej Smętkowski az Ukrajna és Lengyelország között helyi és regionális szinten megvalósuló határ menti együttmükődésekkel foglalkozik. Megállapítják, hogy az elmúlt évtizedben sem a határrégió, sem a vizsgált lengyel és ukrán városok (Lviv kivételével) nem profitáltak igazán határ menti fekvésükbỏl. A határrégió gazdasági teljesítménye lengyel és ukrán oldalon egyaránt elmarad a nemzeti átlagtól. A határhoz közeli lengyel területeken folytatott kereskedelmi tevékenység ezért a közép-lengyelországi gyártók és az ukrán vásárlók közötti közvetítésre korlátozódik. A két ország közötti kereskedelmi mérleg a feldolgozott termékekből álló lengyel export és a fóként nyersanyagokat tartalmazó ukrán import miatt jelentős lengyel többletet mutat.

$\mathrm{Az}$ árszínvonalbeli különbségek a határrégióban a kiskereskedelem fellendüléséhez (szabadtéri piacok) vezettek, azonban a lakosság korlátozott vásárlóereje, az árak kiegyenlítődése és a határ menti kereskedelmet érintő korlátozások miatt e tevékenységek jelentősége csökkent. Napjainkra a kereskedelem e formáját a hivatalosan regisztrált kapcsolatok váltották fel, s ezek forgalma egyre növekszik. Ez talán már egy új fejlődési szakasz kezdetét jelenti, melynek során a határ menti együttmúkődések tartósabb formái alakulhatnak ki. Lengyelország EU-tagsága és az uniós forrásokhoz való jobb hozzáférés stabilizáló tényezỏt jelent a kapcsolatok szempontjából, de a lengyel-ukrán határ külső uniós határrá válása kétségtelenül nehezíteni fogja a kapcsolatok kiépítését, és szükíti az együttmüködés lehetőségeit a határ menti területeken.

\section{IV) Határon átnyúló együttmüködés és regionális fejlesztés az egykori külső határokon}

A könyv utolsó fejezetében található két tanulmány a német-lengyel határrégió (az egykori uniós külső határvidék) fejlődési folyamatait mutatja be. Grzegorz Gorzelak véleménye szerint a német-lengyel határrégióban megvalósult együttmüködéseknek egyértelmủen pozitív eredményei voltak a lengyel közösségek számára. Az önkormányzatoknak együtt kellett müködniük a regionális és nemzeti kormányzat számos szintjével, a különböző uniós szervekkel és egymással is, ami a szervezetek megerősödéséhez vezetett és lehetőséget teremtett az európai integráció potenciális előnyeinek kiaknázására. Érdekes módon a határ lengyel oldalán, ahol a települések kevesebb uniós pénzt kaptak, az együttmüködés elönyei sokkal kézzelfoghatóbban látszanak. A határ másik oldalán szembe kellett nézni a társadalmi átalakulás folyamataival és a kelet-nyugati ellentétek kiéleződésével, ami a a lakosság kőzös európai célok megvalósítása iránti elkötelezettségét korlátozta.

A kötet zárótanulmányában Hans-Joachim Bürkner kevésbé derúlátó a németlengyel együttmúködés eredményeit illetỏen. Igaz, ő elsősorban a határ német oldalára és a kelet-német társadalmi és gazdasági átalakulással kapcsolatos problémákra koncentrál. A térség fejlődési problémái (a magas munkanélküliségi ráta, a beruházások hiánya és a csökkenő népesség) a tartós perifériára kerülés veszélyét hordozzák magukban. A számtalan kezdeményezés ellenére a lengyel-német határ menti együttmüködések regionális fejlődésre gyakorolt hatása korlátozott volt. A néhány 
látványos sikertörténeten kívül (közös egyetem létrehozása Frankfurtban és Slubice városában, vízkezelő berendezés Guben/Gubin városában) a határrégió nagyon megosztott maradt. A helyi önkormányzatok és a civil szférába tartozó szervezetek közötti párbeszéd megindult ugyan, de a határon átívelő vállalkozói hálózat gyengén fejlett maradt. A szerző bemutatja az EU, illetve a lengyel és a német állam gazdaságfejlesztési prioritásait, valamint a regionális igények között feszülő ellentéteket. A határ mindkét oldalán a fizikális értelemben vett infrastruktúrafejlesztés jelenti a regionális fejlesztések fỏ irányvonalát. A tanulmány azt sugallja, hogy az intraregionális hálózatok fejlesztése és a regionális identitás kialakítása e régió számára legalább ugyanolyan, ha nem nagyobb jelentőséggel bír. 